\title{
Menggali Potensi Musik Rohani
}

December 15, 2019

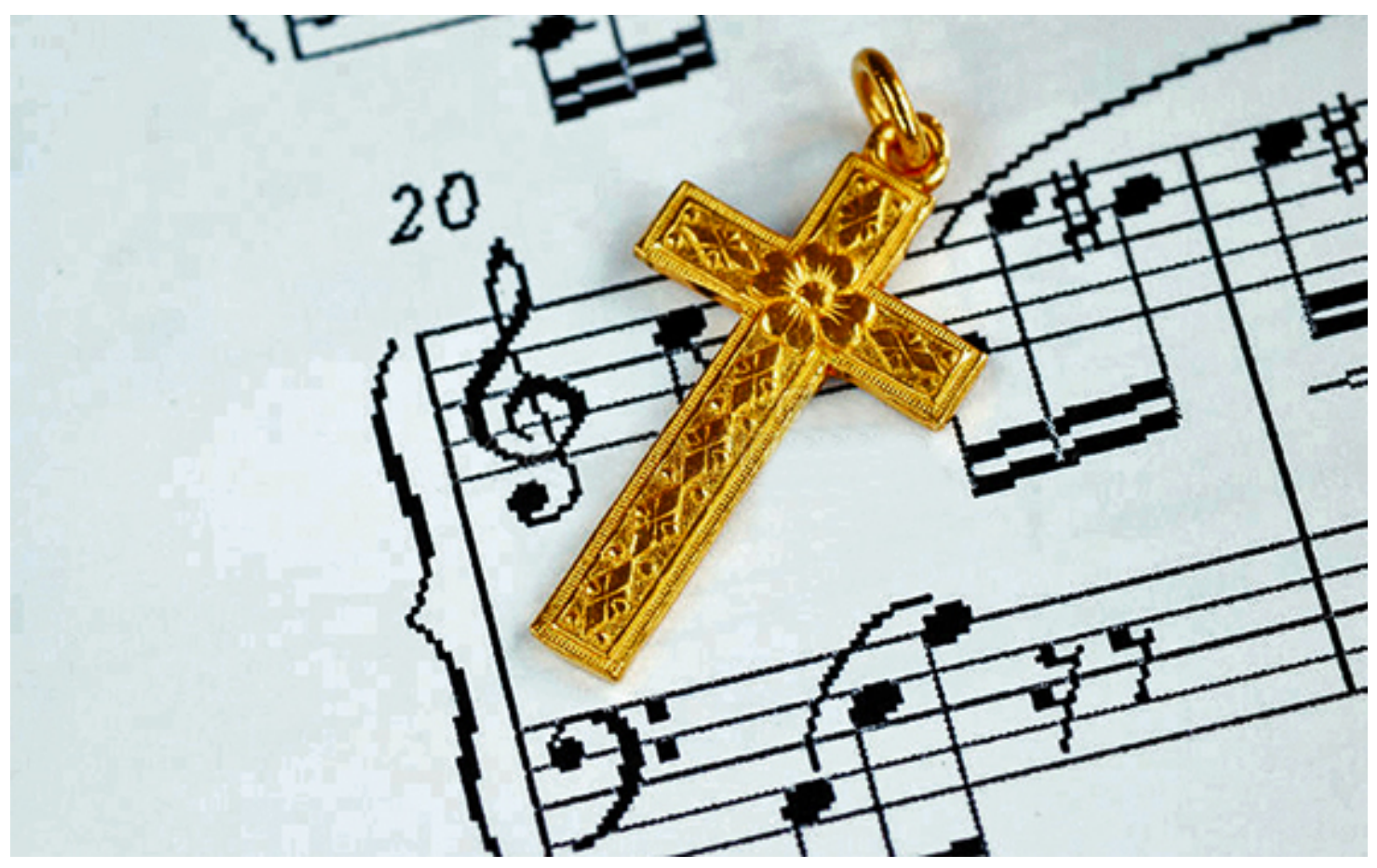

Rate this post

HIDUPKATOLIK.com - Keberadaan Lembaga Pemberdayaan dan Pengembangan Pesparani Katolik Nasional (LP3KN) yang mengadakan lokakarya komposisi lagu liturgi berbasis etnik beberapa waktu lalu, rupanya telah menarik perhatian Pater KarlEdmund Prier, SJ. la mengungkapkan gagasannya perihal proses mencipta lagu rohani etnik. Pendapat ini seperti yang tertuang dalam tulisan "Suara Orang yang Terlupa" (HIDUP, Edisi 44, Th ke-73, 3 November 2019).

Dalam tulisan itu, Pater Prier mengingatkan, bahwa mencipta lagu rohani khususnya lagu liturgi etnik, membutuhkan kekuatan rohani dan refleksi mendalam. Kemudian pendiri Pusat Musik Liturgi (PML) Yogyakarta ini memaparkan data, telah begitu banyak lagu khas Indonesia lengkap dengan aransemen dan paduan suara, yang lahir dari tempat dan orang-orang sederhana.

Untuk menguatkan dan menerjemahkan kembali gagasan Pater Prier, Pastor Moses Elias Situmorang, OFMCap lewat tulisannya "Pater Prier dan LP3KN" (HIDUP, Edisi 50, Th ke-73, 24 November 2019) menekankan lagi agar lagu-lagu yang lahir dari orang-orang sederhana seperti petani, nelayan, pemusik di daerah terpencil dipakai dulu. Ditambahkan, “Kamu (LP3KN) hendak membumikan lagu etnik liturgi, tetapi 
pelaksanaan di hotel berbintang. Ikuti proses alamiah, misalnya, kalau mau mencipta lagu etnik liturgi Dayak, ciptakanlah bersama orang Dayak dan di tanah Dayak."

Apa yang diungkapkan oleh Pater Prier dan Pastor Moses sungguh benar dan tidak bisa disangkal, bahwa mencipta lagu etnik liturgi mesti selalu diiringi dengan kegiatan rohani, karena lagu yang akan diciptakan pun digunakan untuk kegiatan rohani. Namun, ada pengenalan yang belum utuh atas LP3KN, sehingga timbul kesan seolah-olah LP3KN hanya soal mencipta lagu etnik atau soal menghabis-habiskan anggaran.

Padahal LP3KN dibentuk untuk menggali potensi yang ada di antara umat Katolik Indonesia dan membangkitkan potensi itu, khususnya dalam bidang seni/musik rohani. Penyelanggaraan Pesparani I di Ambon telah berlangsung sukses 2018 lalu. Saat ini, LP3KN sedang mempersiapkan Pesparani II di Kupang (NTT) tahun 2020. Para pengurus yang ada di LP3KN dan LP3KD ini pun bekerja tanpa digaji, dan semua bahu-membahu demi suksesnya penyelenggaraan Pesparani, baik di tingkat nasional maupun di tingkat daerah.

Jadi, mencipta lagu liturgi etnik, menurut hemat saya, merupakan salah satu kegiatan yang dilakukan oleh LP3KN, yang kebetulan dilaksanakan di sebuah hotel di Jakarta beberapa waktu lalu. Masalah tempat ini pun kemungkinan hanya demi praktisnya di mana perwakilan dari daerah seluruh Indonesia bisa berkumpul bersama.

Penyelenggaraan lokakarya komposisi lagu itu pun tidak tergolong instan, karena dua bulan sebelum berkumpul di Jakarta, para seniman daerah telah diberikan tugas untuk mempelajari, dan merekam lagu etnik daerahnya. Kemudian mencipta lagu etnik untuk dibawa ke lokakarya untuk selanjutnya dibahas bersama. Tentu saja seluruh proses ini berlangsung dalam suasana rohani dan doa.

Maka upaya yang dilakukan LP3KN melalui bidang komposisi/penciptaan lagu untuk menambah perbendaharaan lagu-lagu rohani khas daerah Indonesia mestinya perlu diapresiasi. Tentu saja dalam penyelenggaraan mungkin masih ada kekurangan. Walaupun demikian, segala kritik membangun demi perbaikan penyelenggaraan Pesparani dan kinerja LP3KN selalu dinantikan, karena kritik adalah salah satu bentuk perhatian dan kecintaan terhadap LP3KN.

\section{Raja Oloan Tumanggor}

HIDUP NO.50 2019, 15 Desember 2019 